\title{
PRODUCTION OF MANGIUM (Acacia mangium) WOOD VINEGAR AND ITS UTILIZATION
}

\author{
Tjutju Nurhayati ${ }^{1}$, Han Roliadi ${ }^{1}$ and Nurliani Bermawie ${ }^{2}$
}

\begin{abstract}
Production of wood vinegar from mangium (Acacia mangium) wood bolts/pieces with their diameter of $317 \mathrm{~cm}$, length of $3067 \mathrm{~cm}$, moisture content of $84.4 \%$, and specific gravity of 0.52 conducted in a dome-shaped kiln with $1.2 \mathrm{~m}^{3}$-capacity afforded a yield of $40.3 \%$. The mangium wood vinegar was produced through condensation (cooling) of smoke/gas fractions released during the charcoaling (carbonization) process of mangium wood. The process could be regarded as an integrated production of wood vinegar and charcoal. The yield of wood vinegar combined with the resulting charcoal was $73.9 \%$ based on the dry weight of inputed mangium wood. Results of chromatography analysis on mangium wood vinegar as conducted in Japan revealed its organic acid content at $73.9 \mathrm{ppm}$, phenol content $8.09 \mathrm{ppm}$, methanol $3.34 \mathrm{ppm}$, acidity degree $4.91 \mathrm{ppm}$, and pH 3.89. Similar analysis on the mangium wood vinegar was conducted in Indonesia's laboratories, and the results were comparable with those of Japan. Results of inhibition testings on particular microorganisms (i.e. Pseudomonas aeroginosa, Stafilococcus aureus, and Candidi albicans fungi) indicated that the mangium wood vinegar could inflict antimicrobe action on those microorganism with its effectiveness somewhat below that of liquid betel soap which could be purchased from drugstores. The experimental use of mangium wood vinegar at 3-5\% concentration on ginger (Zingiber officinale var. white ginger) plants revealed significantly positive growth responses/ characteristics with respect to their height, leaf length, and sprout/shoot development, in comparison with the untreated ginger plants (control). Such responses/characteristics were not significantly different from those using atonik's growth hormone. Likewise, the preliminary use of mangium wood vinegar at 2-percent concentration on teak (Tectona grandis) plants, end stacks of Shorea leprosula and Swietenia mahagoni plants, and rice plants have inflicted their favorable growth responses/characteristics as well.
\end{abstract}

Keywords: mangium wood, kiln, wood vinegar, charcoal, plants, microorganisms

\section{INTRODUCTION}

Wood vinegar is an acidic liquid which smells unfavorable. It is originated from smoke/vapor waste fraction released during charcoal manufacture and further sustained through a condensation process (Anonim, 2001). Wood vinegar can be regarded as one of forest products commodities developed in the environment era. This smoke/vapor waste reveals high potential affording the yield in the range of $70-80 \%$ (Anonim, 1998). So far, it has not been utilized effectively yet. It escapes freely to the air as pollutants (Anonim, 2003).

\footnotetext{
${ }^{1}$ Forest Products Technology Research and Development Center, Bogor

${ }^{2}$ Institute for Spice and Medicinal Crops, Bogor
} 
According to Yatagai (2004), wood vinegar consists of chemical compounds in a great number (approximately 200 compounds) with $80-90 \%$ moisture content and $10-20 \%$ organic components. Such components are among others organic acids, alcohols, neutral compounds, phenol, and nitrogen-containing chemicals. Recent utilization of wood vinegar is as plant-growth accelerator, weed control, and repellents against small animals such as cat, centipede, ants, mites, and termites. Other utilizations are as deodorizer, microorganism control, and fungi prevention. In web site (Anonim, 2002), it is described that wood vinegar can be used for synthesis of chemical products and for gardening-works e.g. flower plants, fruit plants, and vegetables. The indicative role and use of wood vinegar associated with the plant growth are among others by (1) spraying it to the leaf portions thereby inducing the healthier plant growth; (2) adding it to the soil as organic fertilizer; and (3) as $100 \%$ natural fertilizer; (4) to some extent substituting for chemical synthetic fertilizer; and (5) reducing or controlling insects or parasitic organisms.

In this narration, the mangium wood vinegar is brought to attention on consideration that the growth increment and potential of mangium (Acacia mangium) tree forest are quite significant. The mangium species affords the wood growth at $25 \mathrm{~m}^{3}$ per hectare (ha) per year thereby becoming remarkable reserves for the production material of wood vinegar as well as its corresponding charcoal in a continual and sustainable manner. $A$. mangium forest with 215-ha area and 7-year increment is able to produce 8.3 tons of wood vinegar per month and concurrently 6.7 tons of charcoal per month. This narration aimed to indicate the possible beneficial uses of mangium wood vinegar as organic fertilizer, plant-growth hormone, bactericide, and anti-microbe action.

\section{MATERIALAND METHODS}

\section{A. Location}

The experiment took place in the Laboratory of Research and Development Center for Forest Products Technology, Bogor. Small-diameter mangium wood materials were procured from thinning results of 9-year old mangium plantation area administratively under the State Forest Enterprise (Perum Perhutani), Bogor district. Further, the trial test of wood vinegar utilization was conducted at the Forest and Nature Conservation Research and Development Center, the Research Institute for Spice and Medicinal Crops, and Veterinary Institute, all situated in Bogor.

\section{B. Material and Equipment}

The experiment of wood vinegar production consumed as much as $5 \mathrm{~m}^{3}$ of mangium wood further used for charcoal production in the dome-shaped carbonization kiln with 1.2$\mathrm{m}^{3}$ capacity and constructed of bricks, and in the portable kiln with $0.3-\mathrm{m}^{3}$ capacity and constructed of stainless steel. The charcoal production experiment in each of the two kilns was replicated 2 times. Both kilns (i.e. dome-shaped brick kiln and portable steel kiln) were equipped with cooling-water unit that consisted of mantel-model cooling, upright cooling, 
and wood-vinegar collector. The water was automatically circulated using pump motor to the cooling unit from the water tower of 500 liter capacity and then collected to as many as 2 drums of 200 liter capacity. Other related equipments were saw machine for the sawing of wood, plastic drums, balance, scoop, and thermometer.

\section{Methods}

Pieces of mangium wood approximately $50 \mathrm{~cm}$ in length were charged into the kiln until its inside became full and dense. Each of the wood pieces was weighed, and its length and diameter were measured. Several wood pieces were separated and allocated for the examination of moisture content, specific gravity, and calorific value.

The initial firing was with firewood ignited in the fire mouth of the kiln. Further, the flame intensity was decreased after the wood pieces started burning and then evenly spreading. Afterwards, the fire mouth was closed. Perfect burning could proceed by ingenuously regulating the intake air into the kiln, and concurrently opening wide the air holes (pits) to accelerate the burning of wood. Further, the closing or lessening of air holes could extinguish the flame of the burning-wood and further induced the wood burning under limited oxygen (or air). It is called as charcoaling (carbonization) process. The smoke/vapor as released during the carbonization was flown to the cooling unit thereby rendering condensation of the smoke/vapor into liquid-phase form. It is called wood vinegar. The condensed smoke/vapor (wood vinegar) was collected into plastic drums. The carbonization of the wood in the kiln was monitored stage by stage based on the increase in temperature as indicated by the thermometer. When the temperature reached $400-450^{\circ} \mathrm{C}$, then the condensing or cooling process was terminated implying that the production of wood vinegar ended in this stage. All air holes were tightly closed. Afterwards, there was a stage of purification of carbonized product (charcoal) followed by the cooling of kiln that in all could lasted for 3 - 5 hours. If needed, the cooling stage could be prolonged for 2 - 3 days, and afterwards the resulting charcoal was removed from the kiln.

The collected wood vinegar was weighed and filtered using cloth to separate it from the tar and dirt or unexpected matters. The separation could be performed by distilling the wood vinegar at $110^{\circ} \mathrm{C}$. The filtered wood vinegar before being used for particular purposes (e.g. as plant growth agent and organic fertilizer) was analyzed for its chemical components using sophisticated chromatography methods, i.e. high performance liquid chromatography (HPLC). In addition, the trial use of filtered wood vinegar to inhibit the growth of microorganisms (i.e. microbes and fungi) was tested by employing the inhibition-zone method.

The use of dilute or weak wood vinegar to the plants was implemented through a spraying method. It was conducted once a week, and its possible effect on plant growth was examined for its height and harvest results. The utilization method of wood vinegar to the ginger plant species (Zingiber officinale var. white ginger) proceeded from the seed procurement, land/soil cultivation, planting, fertilizing, until the spraying with mangium wood vinegar at four concentrations, i.e. $0 \%$ (as control), $1 \%, 3 \%$, and $5 \%$. The treatment on ginger plants with wood vinegar spraying was compared with other treatment on the plants, i.e. employing bactericide, gandasil's leaf fertilizer, and atonik's growth hormone. 
The spraying started when the age of ginger plants was reaching 3 months old. The ginger was harvested when the plants reached 4 months old. The utilization of wood vinegar to the forestry plants was still in the preliminary trial level among others on the end-stack portion of Shorea leprosula, mahoni and teak plants. Likewise, the preliminary use of wood vinegar on the rice plants took place on the rice fields of farmers.

\section{Data Analysis and Interpretation}

The observed data covered characteristics of ginger materials, parameter of woodvinegar production, yield of wood vinegar, and results of analysis and testing on wood vinegar. The wood vinegar utilization data on ginger plants were analyzed statistically using factorial design. Meanwhile, the wood vinegar production and utilization data were analyzed through the comparison with other research results, literature study and comparative assessment.

\section{RESULTS AND DISCUSSIONS}

\section{A. Characteristics of Mangium Wood as Raw Material}

The characteristics were presented in Table 1.

Table 1. The characteristics of mangium wood for wood vinegar production

\begin{tabular}{|l|c|c|}
\hline \multicolumn{1}{|c|}{ Characteristics } & $\begin{array}{c}\text { Mangium wood charged } \\
\text { into the portable steel } \\
\text { constructed kiln }\end{array}$ & $\begin{array}{c}\text { Mangium wood } \\
\text { charged in the dome } \\
\text { shaped brick kilh }\end{array}$ \\
\hline Moisture content (dry basis), \% & 16.7 & 84.4 \\
\hline Density, g/cm ${ }^{3}$ & 0.52 & 0.54 \\
\hline Diameter of wood bolts (pieces), cm & $3-15$ & $4-17$ \\
\hline Calorific value, $\mathrm{Kcal} / \mathrm{kg}$ & 4255 & 4100 \\
\hline Length of wood pieces, $\mathrm{cm}$ & $50-95$ & $30-67$ \\
\hline Volume of wood pieces, $\mathrm{m}^{3}$ & 0.30 & 0.73 \\
\hline Wet weight, kg & 184.5 & 519.4 \\
\hline Number of wood bolts (pieces) & 48 & 139 \\
\hline
\end{tabular}

${ }^{1)}$ For one batch operation (wood vinegar production) 
It turned out that the moisture content of mangium wood charged into the portable steel kiln was much lower than that into dome-shaped kiln. Therefore, the mangium wood prior to the wood vinegar production in the latter kiln was initially dried, while the one in the former kiln was undried.

The diameter of mangium wood bolts (pieces) ranged about $3-17 \mathrm{~cm}$ and was regarded as small. Mangium wood pieces with such small diameter were not categorized as commercial sizes. The total volume and weight of mangium wood pieces loaded or charged into the portable steel kiln were less than those into the dome-shaped brick kiln

\section{B. Production of Wood Vinegar From Mangium Wood}

Tabel 2 presents the parameters employed in the integrated production of charcoal and wood vinegar from $A$. mangium wood. The wood vinegar production started at $110-120^{\circ} \mathrm{C}$ (in the dome-shaped brick kiln) and $100-130^{\circ} \mathrm{C}$ (in the portable steel kiln) and ultimately ended at $520^{\circ} \mathrm{C}$ and $485^{\circ} \mathrm{C}$, respectively. The cooling or condensing process of the smoke/vapor fraction into the liquid-phase form (i.e. wood vinegar) was lasted for consecutively 64 hours and 28 hours, while the integrated charcoaling (carbonization) process proceeded for 77 and 30 hours, respectively.

Table 2. The employed parameters in the production of wood vinegar from A. Mangium wood

\begin{tabular}{|l|c|c|}
\hline \multicolumn{1}{|c|}{ Parameters } & $\begin{array}{c}\text { Production in the dome } \\
\text { shaped brick kiln }\end{array}$ & $\begin{array}{c}\text { Production in the } \\
\text { portable steel kiln }\end{array}$ \\
\hline $\begin{array}{l}\text { Weight of feed (fire-starting) wood, } \\
\mathrm{kg}\end{array}$ & 5 & 1 \\
\hline $\begin{array}{l}\text { Duration of initial firing (burning), } \\
\text { hours }\end{array}$ & 6 & 2 \\
\hline $\begin{array}{l}\text { Initial temperature of wood } \\
\text { vinegar production, }{ }^{\circ} \mathrm{C}\end{array}$ & 120 & 150 \\
\hline Duration of production, hours & 64 & 485 \\
\hline Final temperature, ${ }^{\circ} \mathrm{C}$ & 510 & 30 \\
\hline $\begin{array}{l}\text { Duration of charcoaling } \\
\text { (carbonization), hours }\end{array}$ & 77 & 2 \\
\hline $\begin{array}{l}\text { Duration of the subsequent } \\
\text { evaporation, hours }\end{array}$ & 5 & 740 \\
\hline Final temperature, ${ }^{\circ} \mathrm{C}$ & 820 & $5-6$ \\
\hline $\begin{array}{l}\text { Flow rate of cooling water, } \\
\text { liters/minute }\end{array}$ & $5-6$ & 1 \\
\hline Cooling duration of the kiln, hours & 4 & 47.6 \\
\hline $\begin{array}{l}\text { Yield of the produced wood vinegar, } \\
\text { kg }\end{array}$ & 113.4 & 38.7 \\
\hline $\begin{array}{l}\text { Yield of the concurrently produced } \\
\text { charcoal, kg }\end{array}$ & 94.6 & \\
\hline
\end{tabular}


The wood vinegar production began when the inside kiln temperature reached 100 $130^{\circ} \mathrm{C}$. It was presumed that at the temperature the water dehydration inside the wood had proceeded intensively, and consequently the produced wood vinegar contained little amount of water. At about $150-250^{\circ} \mathrm{C}$, an endothermic process occurred and external energy supply was no longer needed. There proceeded an intensive thermal decomposition of extractive components, cellulose, and lignin marked with the release of smoke/gas fractions containing among others acetic acid, formic acid, alcohols, small amount of phenol, methane, carbon dioxide, and carbon monoxide. These gases could behave as fuel bringing about an exothermic process. In the subsequent stage at about $400-500^{\circ} \mathrm{C}$, a complete thermal decomposition of lignin and cellulose occurred forming or leaving behind a solid mass which is called charcoal. The rate of wood vinegar production was consecutively $8.12 \mathrm{~kg}$ per hour (in the dome-shaped brick kiln) and $6.58 \mathrm{~kg}$ per hour (in the portable steel kiln).

At $400-500^{\circ} \mathrm{C}$, the smoke/gas fractions became bluish white in color indicating that those fractions contained light-weight tar and no longer wood vinegar. Therefore, the production of wood vinegar at this temperature range was considered as ceased and hence it was terminated. In addition, the production of wood vinegar could be characterized from the color of smoke/gases. The most appropriate or optimal temperature of the smoke/gases was $70-80^{\circ} \mathrm{C}$ whereby the temperature inside the kiln ranged about $500-600^{\circ} \mathrm{C}$. Above $500^{\circ} \mathrm{C}$ temperature, the purification of charcoal occurred releasing a smoke that contained hydrogen gas which was marked by its white color.

In Table 3, there were disclosed the yields of mangium wood vinegar produced in the dome-shaped brick kiln as well as in the portable steel kiln. On the basis of wet weight of the input wood, the yields of wood vinegar produced from the former and the latter kilns were relatively similar ( $21.8 \%$ vs. $20.1 \%$, respectively). However, the yields became remarkably different when it was calculated on the basis of dry wood weight $(40.3 \%$ vs. $24.5 \%)$. The production of wood vinegar per $\mathrm{m}^{3}$ of input mangium wood in the dome-shaped brick kiln was higher than that in the portable steel kiln (129.5 kg vs. $116.3 \mathrm{~kg}$, respectively). Likewise, the rate production of wood vinegar that in the former kiln was greater than in the latter kiln (i.e. $1.77 \mathrm{~kg}$ per hour vs. $1.34 \mathrm{~kg}$ per hour). Similar case occurred for the production of wood vinegar, i.e. $60.6 \%$ (in the dome kiln) vs. $39.9 \%$ (in the portable kiln). Such differences could be attributed to the initial moisture contents of the input mangium wood during the early stage of wood vinegar production in the kilns, i.e. $16 \%$ in the portable steel kiln and $84 \%$ in the dome-shaped brick kiln. Moreover, the initial temperature of wood vinegar production in the dome kiln started at $120^{\circ} \mathrm{C}$ while in the portable kiln at $150^{\circ} \mathrm{C}$. 
Table 3. Yields of wood vinegar and charcoal in their integrated production from mangium wood

\begin{tabular}{|l|c|c|}
\hline \multicolumn{1}{|c|}{ Parameters } & $\begin{array}{c}\text { Production in the } \\
\text { dome-shaped brick kiln }\end{array}$ & $\begin{array}{c}\text { Production in the } \\
\text { portable steel kiln }\end{array}$ \\
\hline $\begin{array}{l}\text { Yield of wood vinegar (on the basis of } \\
\text { wet wood weight), \% }\end{array}$ & 21.8 & 20.1 \\
\hline $\begin{array}{l}\text { Yield of wood vinegar (on the basis of } \\
\text { dry wood weight), \% }\end{array}$ & 40.3 & 24.5 \\
\hline $\begin{array}{l}\text { Production of wood vinegar per } \text { m }^{3} \text { of } \\
\text { mangium wood, } \mathrm{kg} / \mathrm{m}^{3}\end{array}$ & 129.5 & 39.9 \\
\hline $\begin{array}{l}\text { Yield of wood vinegar (condensed } \\
\text { smoke/gases) from the total smoke/ } \\
\text { gas fractions as released, \% }\end{array}$ & 60.6 & \\
\hline $\begin{array}{l}\text { Yield of integrated products } \\
\text { (charcoal + wood vinegar) on } \\
\text { the basis of wet wood weight, \% }\end{array}$ & 37.8 & 42.3 \\
\hline $\begin{array}{l}\text { Yield of integrated products } \\
\text { (charcoal + wood vinegar) on } \\
\text { the basis of dry wood weight, \% }\end{array}$ & 73.9 & 49.3 \\
\hline
\end{tabular}

The cooling process of the smoke/gas fractions in the dome-shaped brick seemed to proceed effectively. This is because as much as $60 \%$ or almost two third of the smoke/gas fractions could be condensed into the liquid-phase form (i.e. wood vinegar). This implied that the integrated production of wood vinegar and charcoal from mangium wood could inflict the minimization of the smoke/gas wastes as released to the atmosphere.

In Indonesia, it was recorded about 1062 units of small-scale wood vinegar industries using Acacia mangium wood, and 2 units of similar scale industries using other wood species, e.g. puspa, eucalyptus, rubber wood, gelam, etc (Nurhayati et al., 2002). Meanwhile, there was only one unit of middle-scale wood vinegar industry using wood sawdust. In general, those industries still relied on the charcoal as the main product and so far have not yet utilized the smoke/gas fraction as released during the charcoal processing. If the yield of charcoal were assumed to be $20 \%$, then as much as $80 \%$ of the smoke/gas fraction just woul escape freely upwards thereby polluting the atmosphere. This implied that the utilization of wood in the charcoaling process is not yet efficient. In 1997, charcoal production of Indonesia was recorded 480 tons (Anonim, 1998) implying that the amount of escaped smoke/gas fraction reached 1920 tons. Further, under the assumption that some $30 \%$ of the smoke/gas fractions could be condensed into wood vinegar, then roughly 400 tons of it could have been produced/collected. These overall figures revealed that implementing integrated charcoal and wood vinegar production in small-scale as well as middle-scale industries can expectedly overcome such high amount of smoke/gas fraction released during carbonization process. 


\section{The Characteristics of Wood Vinegar}

Table 4 described the results of analysis on wood vinegar using chromatography methods performed at the Laboratory of Post-Harvest Agriculture Products in Indonesia. The chromatography analysis for the contents of organic acids in wood vinegar could only be conducted at the University of Tokyo (Japan) due to unavailability of chemical solution standard for those acids in Indonesia's laboratory.

Table 4. Chemical analysis on the mangium wood vinegar using chromatography methods

\begin{tabular}{|c|l|c|c|c|}
\hline No. & \multicolumn{1}{|c|}{$\begin{array}{c}\text { Kinds of organic } \\
\text { compounds }\end{array}$} & $\begin{array}{c}\text { Wood vinegar } \\
\text { produced in the } \\
\text { portable steel kiln }\end{array}$ & $\begin{array}{c}\text { Wood vinegar } \\
\text { produced in the } \\
\text { dome-shaped } \\
\text { brick kiln }\end{array}$ & $\begin{array}{c}\text { Wood vinegar } \\
\text { analyzed in } \\
\text { Japan* }\end{array}$ \\
\hline 1. & Organic acid, ppm & - & - & 73.59 \\
\hline 2. & Acetic acid, ppm & 19.76 & 12.33 & - \\
\hline 3. & Methanol, ppm & 4.93 & 3.59 & 3.34 \\
\hline 4. & Phenol, ppm & 5.4 & 11.95 & 8.09 \\
\hline 5. & o-Creosol, ppm & 7.99 & 17.2 & - \\
\hline 6. & Furfural, ppm & 7.03 & 4.39 & - \\
\hline 7. & Cyclohexane, ppm & 0.54 & 4.56 & - \\
\hline 8. & Specific gravity & 1.008 & 1.013 & 1.022 \\
\hline 9. & Acidity degree & 3.74 & 3.57 & 4.91 \\
\hline 10. & pH & 3.40 & 3.39 & 3.89 \\
\hline
\end{tabular}

Remarks: "Yatagai (2000)

The identified chemical compounds stated in Table 4 were only small portions of approximately existing 200 compounds. There were some remarkable differences in the quantity of chemical compounds in wood vinegar between the one produced from the dome-shaped kiln and the one from the portable steel kiln. In the portable steel kiln the contents of acetic acid and furfural were higher than those in the dome-shaped kiln. On the other hand, the contents of phenol and o-creosol in the latter were greater than those in the fomer. Compared to the results of Japan's analysis on mangium wood vinegar, there were relatively similar values for the dome-shaped kiln's wood vinegar in the respect of methanol content, phenol content, specific gravity, and $\mathrm{pH}$.

The contents of organic acids in mangium wood vinegar were fairly high and seemed identical with its low $\mathrm{pH}$ and acidity degree. This implies that wood vinegar revealed weak acid behavior. Yatagai (2004) stated the wood vinegar with such behavior could act as accelerator for the plant growth. Likewise, the methanol and furfural compounds could also inflict significant role on such growth acceleration. The phenol and creosol, on the contrary, functioned as plant growth inhibitors.

The various characteristics as incurred by the particular chemical compounds in the wood vinegar could exert beneficial effects on plant growth. Besides being used associated 
with plants, wood vinegar could also act as weed control (e.g. Gramineae, Compositae and Vitaceae), as repellent agent against small animals (e.g. cat, centipede, cow ants and mites), and as particular microorganism control thereby lessening the spread of sugi diseases.

Wood vinegar could also exhibit antimicrobe actions as indicated from the results of the microbiology testings on particular organisms (e.g. Pseudomonas aeroginosa, Stafilococcus aureus and Candidi albicans fungi) that parasitically live around humans or animals. Compared to the liquid betel soap, the wood vinegar could also exert the inhibition or antimicrobe. The antimicrobe effects as incurred by the wood vinegar, however, was somewhat lower than those of liquid betel soap (Table 5).

Table 5. The inhibition zone (antimicrobe action) incurred by wood vinegar on three kinds of microorganisms

\begin{tabular}{|l|c|c|}
\hline \multirow{2}{*}{ Kinds of microorganisms } & \multicolumn{2}{|c|}{ Inhibition zone (mm) incurred by: } \\
\cline { 2 - 3 } & Wood vinegar & Betel soap \\
\hline P. aeroginosa & 18.5 & 15.5 \\
\hline S. aureus & 18.5 & 29 \\
\hline C. albicans & 8.5 & 17 \\
\hline
\end{tabular}

\section{The Utilization of Wood Vinegar}

\section{The Utilization on Gigantic White Ginger (Z. officinale) Plants}

The use of mangium wood vinegar on ginger plants was experimentally employed at three concentrations (i.e. $1 \%, 3 \%$ and $5 \%$ ). When the ginger plants reached one-week age after planting, their growth characteristics were examined or observed. The characteristics were also observed on the untreated one-week old ginger plants (as control), and on ginger plants of similar ages after being treated with other growth-associated agents, i.e. atonic's hormone growth, bactericide and gandasil leaf's organic fertilizer, each with $2 \%$ concentration. The detailed results were presented in Table 6. Further, similar experiments were also implemented on the 3-month old ginger plant (Table 7). Tables 6 and 7 indicated that the use of wood vinegar at 3 to $5 \%$ concentration could positively affect or occasionally be comparable to the growth of ginger plants in comparison with those of the untreated ginger plants and of ginger plants treated with growth-related agents (i.e. bactericide, atonik's growth hormone and gandasil leaf's organic fertilizer). 
Table 6. Average growth percentage of ginger plants several weeks after planting

\begin{tabular}{|c|c|c|c|}
\hline \multirow{2}{*}{$\begin{array}{c}\text { Treatment } \\
\text { description No. }\end{array}$} & \multicolumn{3}{|c|}{ Weeks after planting } \\
\cline { 2 - 4 } & 9 & 13 & 17 \\
\hline 1 & $46.18 \mathrm{efgh}^{1)}$ & $52.35 \mathrm{de}$ & $5078 \mathrm{def}$ \\
2 & $41.41 \mathrm{~h}$ & $43.75 \mathrm{gh}$ & $41.41 \mathrm{~h}$ \\
3 & $10.16 \mathrm{j}$ & $10.16 \mathrm{j}$ & $8.60 \mathrm{j}$ \\
4 & $42.19 \mathrm{~h}$ & $46.88 \mathrm{efgh}$ & $45.31 \mathrm{fgh}$ \\
5 & $50.00 \mathrm{defg}$ & $54.69 \mathrm{~cd}$ & $60.16 \mathrm{bc}$ \\
24 & $60.93 \mathrm{~b}$ & $70.32 \mathrm{a}$ & $67.19 \mathrm{a}$ \\
25 & $29.69 \mathrm{i}$ & $46.88 \mathrm{efgh}$ & $42.19 \mathrm{efgh}$ \\
\hline CV (\%) & \multicolumn{3}{|c}{6.402} \\
\hline
\end{tabular}

\section{Remarks:}

$1=$ control (ginger plants without treatment)

$2=$ treated with bactericide at $2 \mathrm{gram} /$ liter concentration

$3=$ treated with mangium wood vinegar at $1 \%$ concentration

$4=$ treated with mangium wood vinegar at $3 \%$ concentration

$5=$ treated with mangium wood vinegar at $5 \%$ concentration

$24=$ treated with atonik's growth hormone

$25=$ treated with gandasil leaf's organic fertilizer

- Actually, the experiment also involved treatments no. $5,6, \ldots \ldots$ until... 23 , but their corresponding data were excluded in the statistical analysis and Duncan's multiple range (DMR) test, because they referred to those of mangium wood vinegar added with $(+)$ mangium charcoal, and of wood vinegar manufactured from wood other than mangium species (i.e. mangrove and pine/tusam wood)

- Letters: a, b, c, d, e, f, g, h, and are grouping that resulted the DMR test

${ }^{1)}$ Figures followed by the same letters in the same column are not significantly different based on the DMR test at 5 $\%$ level $(a>b>c>d>e>f>g>h>$ i)

$-\mathrm{CV}=$ coefficient of variation 
Tabel 7. The effect of using wood vinegar on the growth characteristics of ginger plants (3 months after planting)

\begin{tabular}{|c|c|c|c|c|c|c|c|c|}
\hline \multirow[b]{2}{*}{$\begin{array}{c}\text { Treatment } \\
\text { descrip- } \\
\text { tion }^{1)}\end{array}$} & \multicolumn{8}{|c|}{ Growth characteristics ${ }^{2)}$} \\
\hline & \multicolumn{2}{|c|}{$\begin{array}{c}\text { Number of } \\
\text { sprouts/ } \\
\text { shoots }\end{array}$} & $\begin{array}{c}\text { Height of } \\
\text { plants }\end{array}$ & $\begin{array}{c}\text { Number of } \\
\text { leaves }\end{array}$ & \multicolumn{2}{|c|}{$\begin{array}{c}\text { Length of } \\
\text { leaves }\end{array}$} & $\begin{array}{l}\text { Width of } \\
\text { leaves }\end{array}$ & $\begin{array}{c}\text { Number of } \\
\text { winding } \\
\text { stems }\end{array}$ \\
\hline 1 & 3.95 & $\mathrm{bc}^{1)}$ & $24.05 \mathrm{ab}$ & $25.2 \mathrm{~d}$ & 17.85 & & $2.55 \mathrm{~b}$ & $2.35 \mathrm{~b}$ \\
\hline 2 & 5.05 & $\mathrm{ab}$ & $23.2 \mathrm{ab}$ & $36.65 \mathrm{abcd}$ & 18.05 & & $2.45 \mathrm{bc}$ & $2.25 \mathrm{~b}$ \\
\hline 3 & 3 & c & $11.85 \mathrm{~b}$ & $15.05 \mathrm{e}$ & 11.75 & b & $2.0 \mathrm{c}$ & $1.45 \mathrm{c}$ \\
\hline 4 & 3.15 & c & $25.7 \quad a b$ & $35.65 \mathrm{bc}$ & 18.75 & a & $2.45 \mathrm{bc}$ & $2.3 \mathrm{~b}$ \\
\hline 5 & 6 & a & $28 \mathrm{ab}$ & $43.7 \mathrm{a}$ & 20.9 & a & $2.55 \mathrm{~b}$ & $2.35 \mathrm{~b}$ \\
\hline 12 & 4.45 & $a b$ & $23.25 \mathrm{ab}$ & $30.75 \mathrm{~cd}$ & 17.95 & a & $2.35 \mathrm{bc}$ & 3.3 a \\
\hline 13 & 5.75 & a & 33.45 a & $43.25 \mathrm{ab}$ & 21.95 & a & $4.1 \mathrm{a}$ & $2.6 \mathrm{~b}$ \\
\hline 14 & 6 & a & $24.2 \quad \mathrm{~b}$ & $36.8 \mathrm{abc}$ & 18.7 & a & $2.55 \mathrm{~b}$ & $2.3 \mathrm{~b}$ \\
\hline 24 & 4.45 & $a b$ & $26.5 \mathrm{ab}$ & $34.5 \mathrm{c}$ & 19.5 & a & $2.6 \mathrm{~b}$ & $2.5 \mathrm{~b}$ \\
\hline 25 & 4.1 & $a b$ & $26.35 \mathrm{ab}$ & $26.9 \mathrm{~d}$ & 18.75 & & $2.55 \mathrm{~b}$ & $2.25 \mathrm{~b}$ \\
\hline $\mathrm{CV}(\%)$ & 10.80 & & 28.63 & 9.69 & 10.1 & & 8.36 & 7.83 \\
\hline
\end{tabular}

Remarks:

$1=$ control (ginger plants without treatment)

$2=$ treated with bactericide at $2 \mathrm{gram} /$ liter concentration

$3=$ treated with mangium wood vinegar at $1 \%$ concentration

$4=$ treated with mangium wood vinegar at $3 \%$ concentration

$5=$ treated with mangium wood vinegar at $5 \%$ concentration

$12=$ treated with mangium wood vinegar at $1 \%$ concentration + mangium charcoal

$13=$ treated with mangium wood vinegar at $3 \%$ concentration + mangium charcoal

$14=$ treated with mangium wood vinegar at $5 \%$ concentration + mangium charcoal

$24=$ treated with atonik's growth hormone

$25=$ treated with gandasil leaf's organic fertilizer

- Actually, the experiment also involved treatments no. 6 until 11 and no. 15 until 23, but their corresponding data were excluded in the statistical analysis and.Duncan's multiple range (DMR) test, because they referred to those of vinegar manufactured from wood other than mangium species (i.e. mangrove and pine/tusam wood), either with or without addition of their corresponding charcoal

- Letters: a, b, c, and d are grouping that resulted from the DMR test

${ }^{11}$ Figures followed by the same letters in the same column are not significantly different based on the DMR test at $5 \%$ level $(\mathrm{a} . \mathrm{b}>\mathrm{c}>\mathrm{d})$

$-\mathrm{CV}=$ coefficient of variation 


\section{Preliminary Trial of Ginger Plants on Several Other Plant Species}

The experimental use of wood vinegar on forestry plants, particularly teak (Tectona grandis), and end stacks of Shorea leprosula and Swietenia mabagoni plants, also exhibited positive growth responses. For the teak plants, mangium wood vinegar at 2- $\%$ concentration was sprayed as many as four times until reaching their 2 -month age. On the other hand, end stacks of $S$. leprosula plants which were also sprayed 4 times with $1-2 \%$ mangium wood vinegar exhibited better growth responses, and none of the sprayed plants died. In comparison with the unsprayed plants, as many as $10 \%$ of them died. Likewise, similar spraying was also performed on 1-month old Swietenia mabagoni plants. They revealed better growth responses with respect to length and number of their leaves in comparison with those of unsprayed S. mabagoni plants. The encouraging results of this experiment, however, still deserve further extensive examination to get more convincing confirmation.

The use of wood vinegar on agriculture and vegetable plants, such as rice, cucumber, beans, and tomatoes, as socialized to the farmers for the implementation in their cultivation land also exhibited remarkable results as a biopesticide. The results seemed a little bit below those of using chemical pesticides, however the farmers could take a significant benefit by using wood vinegar as biopesticide which was much cheaper and less harmful to the environment than chemical pesticide. The trial use on 1-month old rice plants, on cucumber plants and on bean plants by spraying method required wood vinegar as much as consecutively 36 liters per ha, 7 liters per ha, and 8 liters per ha.

\section{CONCLUSIONS AND SUGGESTIONS}

1. Production of wood vinegar from mangium wood conducted through the wood carbonization in the dome-shaped brick kiln with $1.2-\mathrm{m}^{3}$ capacity was more favorable than that in the portable steel kiln. In the dome-shaped kiln, the production of wood vinegar from the input mangium wood pieces with the diameter about $3-17 \mathrm{~cm}$ and length $30-67 \mathrm{~cm}$, moisture content $84 \%$ and specific gravity 0.54 was $129.5 \mathrm{~kg}$ per m $\mathrm{m}^{3}$ of wood pieces.

2. Production of wood vinegar could be integrated with charcoal production. The charcoal production proceeded for 77 hours and ended when the inside kiln temperature reached $820^{\circ} \mathrm{C}$. As much as $60.62 \%$ of the smoke/gas fractions could be condensed into the wood vinegar, and the yield of integrated charcoal and wood vinegar production was $73.9 \%$.

3. Chromatography analysis on mangium wood vinegar as performed in Japan revealed specific characteristics, i.e. the contents of organic acid at $73.59 \mathrm{ppm}$, phenol $8.09 \mathrm{ppm}$, methanol $3.34 \mathrm{ppm}$, acidity degree 4.91 and $\mathrm{pH} 3.89$. Similar analysis was also conducted in the Indonesia's laboratories and revealing similar results with the exception of organic acid content.

4. Results of inhibition testings of mangium wood vinegar on particular microorganisms (i.e. P. aeroginosa, S. aureus and C. albicans fungi) revealed its antimicrobe actions. However, the antimicrobe actions incurred by wood vinegar was somewhat below that of betel soap. 
5. The experimental use of wood vinegar at 3\% concentration on the ginger plants indicated favorable growth responses/characteristics in comparison with the untreated ginger plants and the ginger plants treated with other growth-related agents (i.e. atonic growth hormone, bactericide, and handasil leaf's organic fertilizer).

6. Preliminary trial of wood vinegar at $2 \%$ concentration on teak plants, and end stacks of Shorea leprosura and Swietenia mahagoni plants also revealed some positive growth responses/characteristics. Further, the use of wood vinegar as biopesticide on rice plants afforded the production of 5-6.5 tons of husked rice per ha of rice field. As such, it required as much as 36 liters of wood vinegar per ha. It seemed that the farmers preferred wood vinegar (as biopesticide) to chemical fertilizers, because biopesticide was cheaper, no poisonous, and less environmentally harmful. Related to this the use of mangium wood vinegar in the seedlings of forestry plants still needs further more thorough experiment.

7. The production of wood vinegar integrated with that of charcoal as implemented on the mangium wood turned out to be more efficient. This is because two kinds of products (wood vinegar and charcoal) could be concurrently produced with one process. In addition, the qualities of the resulting charcoal were not affected by implementing the wood vinegar production in comparison with those without wood vinegar production.

8. The encouraging results with mangium wood indicated that such wood species with small diameter size resulting from the thinning and former logging of mangium stands could bring beneficial products through its processing into wood vinegar and charcoal.

\section{REFERENCES}

Anonim. 1998. Pengembangan industri pengolahan arang. Direktorat Industri Kayu dan Rotan. Jakarta. .2001. Wood vinegar. Forest Energy Forum No. 9, FAO of United Nations.

2002. Efficacy of wood vinegar. Website: http://www.sumiworld/vinegar.html. Diakses tahun 2003.

2003 Report on fourth fiscal year (2002-2003). Cooperative Biomass Utilization Project Activities between RDCFPT and JIFPRO. Tokyo-Bogor.

Yatagai, M. 2000. Results of chromatography analysis on distilate of tusam (Pinus merkusii) wood vinegan. Professor at Tokyo University (Japan). Communication through the email network (amyatag@mail.ecc.u-tokyo.ac.jp).

2004. Production and utilization of wood carbonization. Makalah pada Seminar Penggalakan Pengembangan Arang dan Cuka kayu. Bogor, 27 Juli.

Nurhayati, T., S. Soleh, Mahpudin and Saepuloh. 2002. Improvement on technics of charcoal production. Scientific Cooperation between RDCFPT and JIFPRO, Bogor. 